\title{
Inherited Variation in Vitamin D Genes and Type 1 Diabetes Predisposition
}

\author{
Marissa Penna-Martinez and Klaus Badenhoop * \\ Division of Endocrinology, Diabetes and Metabolism, Department of Medicine 1, University Hospital Frankfurt, \\ Theodor-Stern-Kai 7, D-60590 Frankfurt am Main, Germany; Marissa.Penna-Martinez@kgu.de \\ * Correspondence: badenhoop@em.uni-frankfurt.de; Tel.: +49-69-6301-5396; Fax: +49-69-6301-6405
}

Academic Editor: Bernhard O. Boehm

Received: 7 February 2017; Accepted: 12 April 2017; Published: 20 April 2017

\begin{abstract}
The etiology and pathophysiology of type 1 diabetes remain largely elusive with no established concepts for a causal therapy. Efforts to clarify genetic susceptibility and screening for environmental factors have identified the vitamin D system as a contributory pathway that is potentially correctable. This review aims at compiling all genetic studies addressing the vitamin $\mathrm{D}$ system in type 1 diabetes. Herein, association studies with case control cohorts are presented as well as family investigations with transmission tests, meta-analyses and intervention trials. Additionally, rare examples of inborn errors of vitamin D metabolism manifesting with type 1 diabetes and their immune status are discussed. We find a majority of association studies confirming a predisposing role for vitamin D receptor (VDR) polymorphisms and those of the vitamin D metabolism, particularly the CYP27B1 gene encoding the main enzyme for vitamin D activation. Associations, however, are tenuous in relation to the ethnic background of the studied populations. Intervention trials identify the specific requirements of adequate vitamin D doses to achieve vitamin D sufficiency. Preliminary evidence suggests that doses may need to be individualized in order to achieve target effects due to pharmacogenomic variation.
\end{abstract}

Keywords: immune modulation; pharmacogenomics; nuclear hormone action

\section{Introduction}

The growing incidence of type 1 diabetes (T1D) is understood to result from an interplay of several factors including environment, nutrition and genetics. One of the environmental and nutritional factors may be a vitamin D deficiency that is highly prevalent and increases the risk for T1D as well as other autoimmune disorders $[1,2]$. In vitro studies could show a protective effect of active vitamin $D$ for cytokine treated human pancreatic islets [3]. This field of research is of continuing interest with a steady increase in publications over recent years. Due to the lack of a causal therapy in T1D, vitamin D research intended to pave the way for novel immune modulatory concepts both for prevention as well as therapy.

Vitamin D is structurally related to the steroid hormones and its mechanism of action also involves a nuclear receptor similar to thyroid, gonadal and adrenal hormones. The physiological effects extend from the classical bone and calcium/phosphate regulation to muscle, vasculature, immunity, skin, gut and brain which explains that the vitamin D receptor (VDR) is expressed on a vast number of cells which respond to vitamin $\mathrm{D}$. The immune effects of vitamin $\mathrm{D}$ on dendritic cells, macrophages and $\mathrm{T}$ lymphocytes have attracted major attention since they hold promise for novel therapies $[4,5]$.

\section{Vitamin D Pathways}

There are two major forms of vitamin D: vitamin $\mathrm{D}_{2}$ and vitamin $\mathrm{D}_{3}$. While $\mathrm{D}_{2}$ (ergocalciferol) is of exogenous origin via food intake, vitamin $\mathrm{D}_{3}$ (cholecalciferol) comes primarily from skin production 
through photochemical reaction of precursors and thereby reflects endogenous synthesis. This is initiated upon cutaneous exposure to ultraviolet (UV) B radiation, resulting in the conversion of 7-dehydrocholesterol (7DHC, present in the skin) to previtamin $\mathrm{D}_{3}$ followed by the thermal isomerization to vitamin $\mathrm{D}_{3}$ [6]. The subsequent hydroxylation of vitamin $\mathrm{D}_{3}$ occurs in the liver mediated by the 25-hydroxylase (CYP2R1) which forms 25-hydroxyvitamin $\mathrm{D}_{3}\left(25(\mathrm{OH}) \mathrm{D}_{3}\right.$, calcidiol), the major circulating human vitamin $\mathrm{D}$ metabolite. A further hydroxylation of $25(\mathrm{OH}) \mathrm{D}_{3}$ by $1-\alpha$-hydrolase (CYP27B1) in the kidney-or in extrarenal tissues such as macrophages-leads to the biologic active 1,25-dihydroxyvitamin $\mathrm{D}_{3}\left(1,25(\mathrm{OH})_{2} \mathrm{D}_{3}\right.$, calcitriol) [7]. The $1,25(\mathrm{OH})_{2} \mathrm{D}_{3}$ binds with high-affinity to the VDR, which heterodimerises with the retinoid $X$ receptor alpha (RXR $\alpha)$. The VDR-RXR $\alpha$ complex translocates into the nucleus and binds to a vitamin D response elements (VDRE) in the regulatory element region of the vitamin D target genes. Vitamin D exerts its genomic effects through the recruitment of transcriptional cofactors to this region regulating a wide variety of biological processes including calcium and phosphate absorption, cell proliferation and differentiation [8]. Approximately 2700 VDR-binding sites exist in the genome [9], explaining the wide-ranging physiologic actions of $1,25(\mathrm{OH})_{2} \mathrm{D}_{3}$. Enzymes regulate the abundance of metabolites: 24-hydroxylase (CYP24A1) limits the excess concentrations of both metabolites, $\left[25(\mathrm{OH}) \mathrm{D}_{3}\right.$ and $1,25(\mathrm{OH})_{2} \mathrm{D}_{3}$ ] by metabolic degradation. In the circulation, most vitamin $\mathrm{D}$ metabolites are transported to various target organs (tissues/cells) bound to a carrier protein, the vitamin D binding protein (DBP). Megalin and cubilin, two multiligand endocytic receptors, are responsible for the internalization of $25(\mathrm{OH}) \mathrm{D}_{3}$ complexed with the DBP into cells [10] (Figure 1).

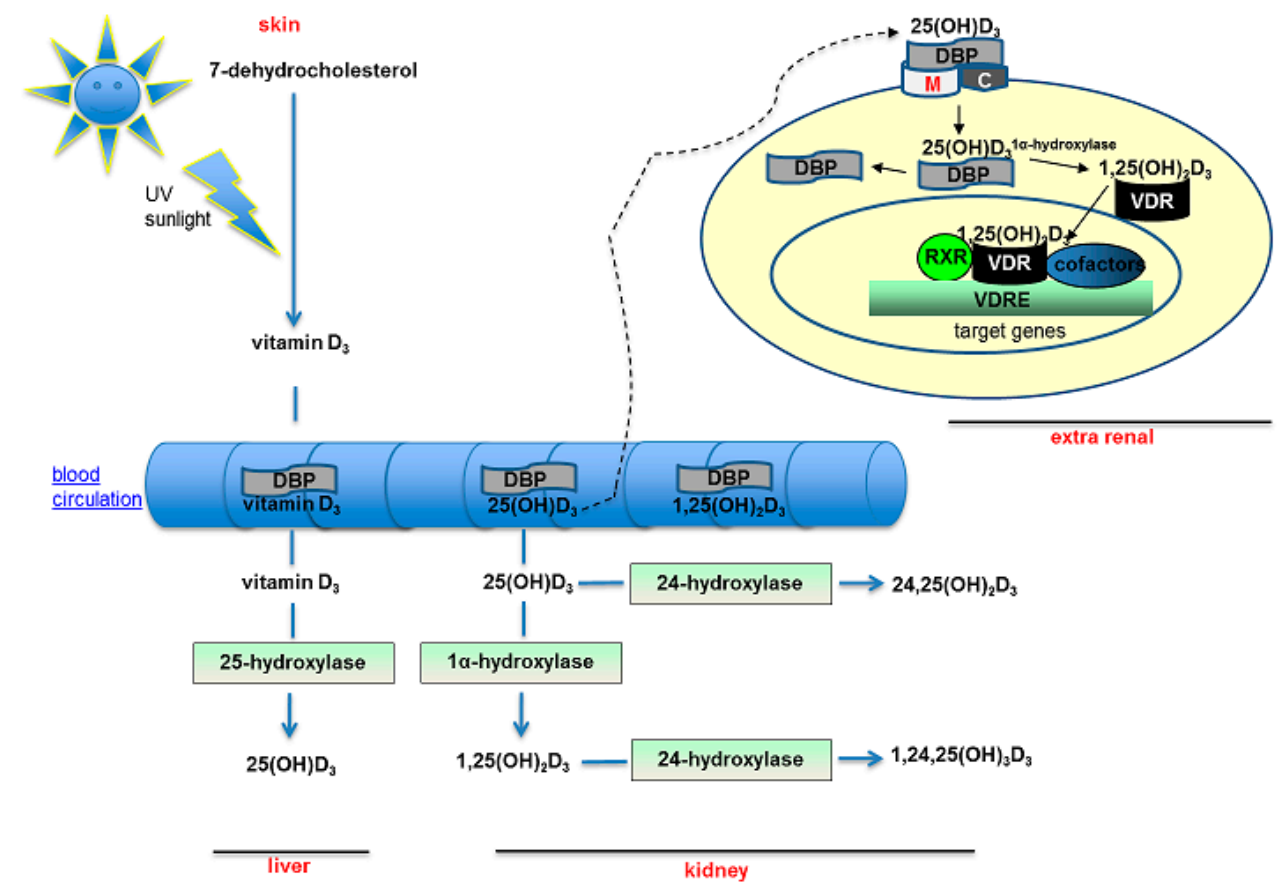

Figure 1. Vitamin D pathway: The vitamin D synthesis goes through a series of hydroxylation steps in which the 25-hydroxylase (CYP2R1) and 1- $\alpha$-hydroxylase (CYP27B1) are involved. The resulting $25(\mathrm{OH}) \mathrm{D}_{3}$ and $1,25(\mathrm{OH})_{2} \mathrm{D}_{3}$ are transported into the circulation bound to the vitamin $\mathrm{D}$ binding protein $(\mathrm{DBP})$. The $25(\mathrm{OH}) \mathrm{D}_{3}$ enters into the cells via the megalin/cubilin complex. Intracellularly, $1,25(\mathrm{OH})_{2} \mathrm{D}_{3}$ binds to the vitamin $\mathrm{D}$ receptor (VDR) and exerts its genomic effects. In this manner, vitamin D can (1) suppress PTH synthesis in parathyroid glands; (2) increase bone mineralization; (3) increase absorption of calcium and phosphate in the intestine; (4) induce the differentiation of immune cells; and (5) improve the haematopoiesis of red blood cells. Finally, the degradation of vitamin D occurs via 24-hydroxylase (CYP24A1). 
The coexpression of the vitamin D system genes (e.g., VDR and CYP27B1) in multiple cell types including lymphocytes, antigen-presenting cells and pancreatic islet cells [11-13] highlights the importance of the vitamin D pathway in T1D.

The $25(\mathrm{OH}) \mathrm{D}_{3}$ concentration as a marker of the vitamin $\mathrm{D}$ status is influenced by environmental and genetic factors. Both sunlight exposure and variants in vitamin $\mathrm{D}$ pathway genes affect circulating $25(\mathrm{OH}) \mathrm{D}_{3}$ levels. Low $25(\mathrm{OH}) \mathrm{D}_{3}$ levels as well as specific vitamin D system gene polymorphisms enhance T1D susceptibility. Since vitamin $D$ biosynthesis is regulated by genes, their polymorphisms (e.g., VDR, CYP2R1, CYP27B1, CYP24A1, DBP and cubilin) may alter the bioavailability as well as target effects of vitamin D metabolites.

\subsection{Vitamin D Receptor Gene}

The VDR belongs to the nuclear receptor family of transcription factors composed of three domains: a modulating $N$-terminal dual zinc finger DNA-binding domain, a $C$-terminal ligand-binding domain and an unstructured region that links the two functional domains [14]. The human VDR gene spans over 100 kilobases $(\mathrm{kb})$ of genomic DNA, located at chromosome 12q13.11, contains eight protein-coding exons 2-9, six untranslated exons 1a-1f, introns and $3^{\prime}$ UTR 1 exons [15]. Exon 1 encodes the $5^{\prime}$ untranslated region; exons 2 and 3 encode the DNA-binding domain, important for the interaction with the VDRE in target genes. The exons 5-9 encode the ligand-binding region responsible for $1,25(\mathrm{OH})_{2} \mathrm{D}_{3}$ binding.

Several single nucleotide polymorphisms (=SNPs; more than 5000) have been described for the human $V D R$ gene (https://www.ncbi.nlm.nih.gov/snp/) and four of them have been intensively studied in relation to T1D susceptibility (Table 1).

These SNPs were identified by their restriction endonuclease cleavage sites comprising rs10735810, also known as rs2228570 (FokI) $\mathrm{T} \rightarrow \mathrm{C}$ change in exon 2, rs1544410 $\mathrm{G} \rightarrow$ A change (BsmI, $\mathrm{G}=\mathrm{b}$ ), rs7975232 $\mathrm{T} \rightarrow \mathrm{G}$ change (ApaI, $\mathrm{G}=\mathrm{a}$ ), both in intron 8 , and rs731236 $\mathrm{T} \rightarrow \mathrm{C}$ change in exon 9 (TaqI, $\mathrm{T}=\mathrm{T})[16]$.

The rs10735810 (FokI) SNP consists of a T to C substitution eliminating the first start codon (ATG) by generation of an alternative start site (ACG) leading to a differently sized protein. The shorter form (424 aa; $\mathrm{C}$ allele or $\mathrm{F}$ allele, methionine at the fourth position) is considered to be more active than the long form (427 aa; $\mathrm{T}$ allele or $\mathrm{f}$ allele, methionine at first position) $[17,18]$. The SNPs rs1544410 (BsmI), rs7975232 (ApaI) and rs731236 (TaqI) are located at the $3^{\prime}$ untranslated region (UTR) of the gene and are without consequences for the VDR protein structure, however, they are strongly linked to a poly(A) microsatellite repeat in the $3^{\prime}$ UTR. The poly(A) sequence in the $3^{\prime}$ UTR region of genes regulates gene expression, especially through the modulation of mRNA stability.

To date, there are 65 publications [19-83] on the association of $V D R$ gene SNPs in T1D: these include case-control datasets $[20,22,23,25-36,39-45,47-50,52,53,55-66,68-70,72-74]$, family studies $[19,21,24,31,32,36,38,46,51,54,57,67,71]$ and meta-analyses [75-83] derived from several populations of different genetic background. A total of 39 publications support an association between VDR SNPs rs7975232 (ApaI), rs1544410 (BsmI), rs731236 (TaqI) and rs10735810 (FokI) alone or in combination with each other, (rs757343 Tru9I, rs1540339 and rs4760648) and T1D [19,21-24,26-30,34-38,40-44,46,48-50,52,53,55,56,59-63,65,68-71,73] (Table 2) in comparison with 16 studies that refute it $[20,25,31,32,39,45,47,51,54,57,58,64,66,67,72,74]$. 
Table 1. Type 1 diabetes (T1D) and vitamin D pathway associated single nucleotide polymorphisms (SNPs).

\begin{tabular}{|c|c|c|c|c|c|c|c|c|}
\hline Acronym & Full Name & Protein Function & $\mathrm{Chr}$ & Position & SNP & locus & Gene Function & $\begin{array}{c}\text { Amino Acic } \\
\text { Change }\end{array}$ \\
\hline$V D R$ & vitamin $\mathrm{D}$ receptor & $\begin{array}{l}\text { transcription factor } \\
\text { transcriptional control of } \\
\text { vitamin D target genes }\end{array}$ & 12 & $12 \mathrm{q} 13.11$ & $\begin{array}{c}\text { rs7975232 } \\
\text { rs10735810 } \\
\text { rs1544410 } \\
\text { rs731236 }\end{array}$ & $\begin{array}{c}\text { intron } 8 \\
\text { exon } 2 \\
\text { intron } 8 \\
\text { exon } 9\end{array}$ & $\begin{array}{c}\text { missense } \\
\text { synonymous }\end{array}$ & $\begin{array}{c}\text { no } \\
\text { Met } \rightarrow \text { Thr } \\
\text { no } \\
\text { Ile } \rightarrow \text { Ile }\end{array}$ \\
\hline CYP2R1 & $\begin{array}{c}\text { vitamin D } \\
\text { 25-hydroxylase }\end{array}$ & $\begin{array}{l}\text { transforming photo-synthesized and } \\
\text { dietary vitamin } \mathrm{D} \text { into } 25(\mathrm{OH}) \mathrm{D}_{3}\end{array}$ & 11 & 11p15.2 & $\begin{array}{l}\text { rs10741657 } \\
\text { rs12794714 }\end{array}$ & $\begin{array}{l}5^{\prime} \text { near gene } \\
\text { exon } 1\end{array}$ & $\begin{array}{l}2 \mathrm{~kb} \text { mRNA transcript } \\
\text { synonymous }\end{array}$ & Ser $\rightarrow$ Ser \\
\hline СҮР27B1 & $\begin{array}{c}25(\mathrm{OH}) \mathrm{D} \\
\text { 1- } \alpha \text {-hydroxylase }\end{array}$ & conversion of $25(\mathrm{OH}) \mathrm{D}_{3}$ to $1,25(\mathrm{OH})_{2} \mathrm{D}_{3}$ & 12 & 12q14.1 & $\begin{array}{l}\text { rs10877012 } \\
\text { rs4646536 }\end{array}$ & $\begin{array}{l}5^{\prime} \text { near gene } \\
\text { intron } 6\end{array}$ & $\begin{array}{l}\text { promoter }(-1260) \\
(+2838)\end{array}$ & no \\
\hline$D B P$ or $G C$ & $\begin{array}{l}\text { vitamin D binding protein or } \\
\text { group-specific component }\end{array}$ & transport of vitamin D metabolites & 4 & $4 q 11.13$ & $\begin{array}{l}\mathrm{rs} 4588 \\
\mathrm{rs} 7041\end{array}$ & exon 11 & $\begin{array}{l}\text { missense } \\
\text { missense }\end{array}$ & $\begin{aligned} \text { Thr } & \rightarrow \text { Lys } \\
\text { Asp } & \rightarrow \text { Glu }\end{aligned}$ \\
\hline CUBN & cubilin & $\begin{array}{l}\text { endocytotic receptors } \\
\text { capable to internalize } \\
\text { vitamin D into the cells }\end{array}$ & 10 & 10p12.33-p13 & rs3740165 & & synonymous & Pro $\rightarrow$ Pro \\
\hline
\end{tabular}

Table 2. T1D and summary of association studies for VDR SNPs. Diabetic retinopathy (DR); diabetic nephropathy (DN); Staphylococcus aureus carriage (SAC); antibodies (Abs).

\begin{tabular}{|c|c|c|c|c|c|c|c|c|c|}
\hline \multicolumn{8}{|c|}{ VDR Gene } & \multicolumn{2}{|c|}{ Susceptibility to T1D SNPs } \\
\hline & Reference & Author & Year & Population & Total & Case & Control & & Comparison Groups \\
\hline 1 & [19] & McDermott et al. & 1997 & Indian & 93 & & & rs1544410, bt, bAT & T1D families \\
\hline 2 & [21] & Pani et al. & 2000 & German & 152 & & & At, Bt, Bat & T1D families \\
\hline 3 & [22] & Chang et al. & 2000 & Chinese (Taiwan) & 405 & 157 & 248 & rs7975232, rs1544410 & T1D/control \\
\hline 4 & [23] & Ban et al. & 2001 & Japanese & 360 & 110 & 250 & rs10735810 & T1D/control \\
\hline 5 & [24] & Guja et al. & 2002 & Romanian & 204 & & & rs10735810, rs731236 & T1D families \\
\hline 6 & [26] & Gyorffy et al. & 2002 & Hungarian & 210 & 107 & 103 & bau & T1D/control \\
\hline 7 & [27] & Fassbender et al. & 2002 & German & 132 & 75 & 57 & rs731236 & T1D/control \\
\hline 8 & {$[28]$} & Taverna et al. & 2002 & French & 200 & 101 & 99 & rs731236 & T1D with/without DR \\
\hline 9 & [29] & Skrabic et al. & 2003 & Croatian (Dalmatian) & 266 & 134 & 132 & BBAAtt & T1D/control \\
\hline 10 & [30] & Motohashi et al. & 2003 & Japanese & 425 & 203 & 222 & rs1544410 & T1D/control \\
\hline \multirow{2}{*}{11} & \multirow{2}{*}{ [34] } & \multirow{2}{*}{ Audi et al. } & \multirow{2}{*}{2004} & Spanish (Barcelona) & 429 & 155 & 274 & rs1544410, rs10735810, bbFF & T1D/control \\
\hline & & & & Spanish (Navarre) & 205 & 89 & 116 & rs1544410, rs10735810, bbff & T1D/control \\
\hline 12 & [35] & Zemunik et al. & 2005 & Croatian (Dalmatian) & 266 & 134 & 132 & rs10735810, FbATU & T1D/control \\
\hline
\end{tabular}


Table 2. Cont.

\begin{tabular}{|c|c|c|c|c|c|c|c|c|c|}
\hline \multicolumn{8}{|c|}{ VDR Gene } & \multicolumn{2}{|c|}{ Susceptibility to T1D SNPs } \\
\hline & Reference & Author & Year & Population & Total & Case & Control & & Comparison Groups \\
\hline \multirow{2}{*}{13} & \multirow{2}{*}{ [36] } & \multirow{2}{*}{ San Pedro et al. } & \multirow{2}{*}{2005} & \multirow{2}{*}{ Spanish (Basque) } & 159 & 71 & 88 & \multirow{2}{*}{ fBAt } & T1D/control \\
\hline & & & & & & 136 & 119 & & T1D families \\
\hline 14 & [37] & Taverna et al. & 2005 & French & 254 & 126 & 128 & rs10735810 & T1D with/without DR \\
\hline 15 & [38] & Ramos-Lopez et al. & 2006 & German & 254 & & & rs9729, rs731236, rs7975232, rs757343 & T1D families \\
\hline 16 & [40] & Xiao et al. & 2006 & Chinese & & 54 & 82 & rs1544410 & T1D/control \\
\hline 17 & [41] & Capoluongo et al. & 2006 & Italian & & 246 & 246 & rs10735810 & T1D/control \\
\hline 18 & [42] & Mimbacas et al. & 2007 & Uruguayan & 45 & & & rs10735810 & T1D families \\
\hline 19 & [43] & Garcia et al. & 2007 & Chilean & 419 & 216 & 203 & BAT & T1D/control \\
\hline 20 & [44] & Shimada et al. & 2008 & Japanese & 1373 & 774 & 599 & rs1544410 & T1D/control \\
\hline 21 & [46] & Boraska et al. & 2008 & Croatian & 160 & & & rs757343, rs757343-rs1544410 & T1D families \\
\hline 22 & [48] & Mory et al. & 2009 & Brazilian & 383 & 189 & 194 & rs1544410 & T1D/control \\
\hline 23 & [49] & Panierakis et al. & 2009 & Greece & 93 & 29 & 64 & rs7975232, rs731236 & T1D with/without SAC \\
\hline 24 & [50] & Panierakis et al. & 2009 & Greece & 196 & 100 & 96 & rs7975232, rs731236, rs1544410, rs10735810 & T1D/control \\
\hline 25 & [52] & Israni et al. & 2009 & Indian & 424 & 233 & 191 & FBAt, fBAT & T1D/control \\
\hline 26 & [53] & Bucan et al. & 2009 & Croatian & 120 & 66 & 54 & rs1544410 & T1D with/without DR \\
\hline 27 & [55] & Kocabas et al. & 2010 & Turkish & 176 & 90 & 86 & rs10735810 & T1D/control \\
\hline 28 & [56] & Martin et al. & 2010 & UK, Irish & 1329 & 655 & 674 & AGT & T1D with/without DN \\
\hline 29 & [59] & Sahin et al. & 2012 & Turkish & 165 & 85 & 80 & rs10735810 & T1D/control \\
\hline 30 & [60] & Mohammadnejad et al. & 2012 & Iranian & 187 & 87 & 100 & rs731236, tAbf, tabF, tAbF & T1D/control \\
\hline 31 & [61] & Bonakdaran et al. & 2012 & Iranian & 114 & 69 & 45 & rs7975232, rs1544410, rs10735810 & T1D/control \\
\hline \multirow{2}{*}{32} & \multirow{2}{*}{ [62] } & \multirow{2}{*}{ Vedralová et al. } & \multirow{2}{*}{2012} & \multirow{2}{*}{ Czech } & 172 & 54 & 118 & rs10735810 & T1D/control \\
\hline & & & & & 250 & 132 & 118 & rs10735810, BBFFAATt & $\mathrm{DN} /$ control \\
\hline 33 & [63] & Frederiksen et al. & 2013 & North American & & 38 & 84 & rs1544410 & T1D+IA/IA \\
\hline 34 & [65] & De Azevedo et al. & 2013 & Brazilian & 421 & 204 & 217 & rs1540339, rs4760648 & T1D/control \\
\hline 35 & [68] & Abd-Allah et al. & 2014 & Egyptian & 240 & 120 & 120 & rs1544410, rs10735810 & T1D/control \\
\hline 36 & [69] & Kamel et al. & 2014 & Egyptian & 102 & 74 & 28 & rs7975232, rs731236 & T1D/control \\
\hline 37 & [70] & Cheon et al. & 2015 & Korean & 194 & 81 & 113 & rs731236, rs1544410 & T1D/control \\
\hline 38 & [71] & Miettinen et al. & 2015 & Finnish & 2854 & & & rs731236, rs1544410 & T1D families \\
\hline 39 & [73] & Mory et al. & 2016 & Brazilian & & 180 & & rs10735810 & T1D with/without Abs \\
\hline
\end{tabular}

rs7975232 (=ApaI), rs10735810 (=FokI), rs1544410 (=BsmI), rs731236 (=TaqI) and rs757343 (=Tru9I). 
The first study from South India examined the distribution of the VDR SNPs (rs7975232 ApaI, rs731236 TaqI and rs1544410 BsmI). It found a preferential transmission of the VDR " $\mathrm{b}$ " allele of the rs1544410 (BsmI) site and haplotypes "bT", "bAT" to affected offspring [19]. In the same line, Abd-Allah et al. (2014) [68] observed in children from Egypt a significantly different rs1544410 (BsmI) genotype

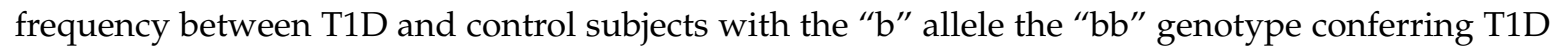
susceptibility. Moreover, significantly more heterozygote carriers of "Aa" and " $\mathrm{Bb}$ " were observed in T1D patients, confirming the risk of the $b$ allele as reported by Bonakdaran et al. (2012) [61] in an Iranian population.

In contrast, Pani et al. (2000) [21] demonstrated other VDR haplotypes "At", "Bt" and "BAt" to confer T1D susceptibility in a German family study. Likewise, the same allele constellation "BBAAtt" was found in a cohort from South Croatia as reported by Skrabic et al. 2003 [29]. Furthermore, the association of T1D with the B allele-as risk enhancing - was confirmed in two case-control Chinese studies (Taiwanese and Han population of Beijing) [22,40], two Japanese studies [30,44] and one genetically heterogeneous Brazilian study [48]. Nevertheless, also the "AA" genotype in Taiwanese and a " $\mathrm{t}$ " allele in Iranian populations have been suggested as risk conferring [22,60]. Accordingly, Ramos-Lopez et al. (2006) demonstrated a higher frequency of alleles " $\mathrm{A}$ " and " $\mathrm{t}$ " within the haplotype composed of the SNPs rs9729, rs731236 (TaqI), rs7975232 (ApaI) and rs757343 (Tru9I) in another family study [38].

Recently, Miettinen et al. (2015) analyzed the genotype distributions of 13 VDR SNPs in a Finnish population consisting of families whose offspring had T1D (cases) and families with healthy offspring (controls) [71] where all VDR SNPs were associated with the $25(\mathrm{OH}) \mathrm{D}_{3}$ levels. Two VDR SNPs (rs1544410 BsmI and rs731236 TaqI) differed in the genotype distributions: "Bb" and " $\mathrm{Tt}^{\prime}$ genotypes were more prevalent (corresponding to " $\mathrm{B}$ " and " $\mathrm{t}$ " allele) than in the control mothers. The investigators suggest that maternal VDR SNPs enhance a child's risk for T1D independent of the child's genotype. The maternal vitamin D status and VDR genotype may hereby regulate in utero development and have an influence on the later T1D risk in conjunction with environmental factors.

In addition, in Chilean T1D patients where the population is characterized by a heterogeneous admixture of people from European and South American Indian descent, a further haplotype "BAT" [43] conferred susceptibility.

Fassbender et al. confirmed the study from Mcdermott et al. (1997) with " $T$ " as risk allele for the development of T1D [19] in a small German cohort [27], a finding later corroborated by Garcia et al. (2007) [43].

Notably, the different haplotypes associated with T1D as reported by Mcdermott et al. (1997) [19] (bAT), Pani et al. (2000) [21] (BAt) and Garcia et al. (2007) [43] (BAT) indicate a variable genetic predisposition to T1D depending on the ethnic origin. This was also shown by Audi et al. (2004) [34] by analyzing the SNP in the start codon of exon 2 (rs10735810 FokI) additional to the rs1544410 (BsmI) SNP in two Spanish populations with different genetic backgrounds (Barcelona and Navarra). A combined genotype showed that the homozygous "bbFF" genotype was more prevalent in T1D patients from Barcelona whereas the homozygous "BBFF" genotype was more frequent in Navarra. Another study conducted by San Pedro et al. (2005) included families of Basque origin where a risk-associated four-locus haplotype (fBAt) was identified [36] confirming the same profile ("BAt") as described by Pani et al. (2000) [21]. Furthermore, haplotype analysis performed in North India showed that the haplotypes "FBAt" and "fBAT" were significantly more frequent in T1D patients [52]. Moreover, those haplotypes differed in comparison to those from South India (bAT) but were found in concordance with the "BAT" haplotype present in Chile $[19,43]$. In an Iranian population, the haplotypes "tAbf", "tabF" and "tAbF" conferred an increased risk for T1D [60].

The genotype and allele distribution of rs10735810 (FokI) VDR SNP differs between patients and controls in many studies, however, the risk allele (F or $\mathrm{f}$ ) also does so among the studies. The "FF" genotype and /or " $\mathrm{F}$ " allele predispose to T1D in Japanese, Rumanian, Uruguayan, Turkish and Iranian populations $[23,24,42,55,59,61]$. The " $F$ " allele and the combination of vitamin D gene "BBFFAATt" 
are even considered to enhance the risk for diabetic complications, particularly diabetic nephropathy (DN) [62]. In contrast, studies from Egypt, Italy and Croatia $[35,41,68]$ observed an association with the "ff" genotype and T1D risk. Mory et al. (2016) [73] found homozygous "ff" to be more frequent in T1D subjects with thyroid antibodies (Abs) and thyroid dysfunction in Brazil. T1D patients carrying the rs10735810 (FokI) SNP with thyroid peroxidase Abs showed an 18-fold risk to develop thyroid dysfunction.

Additionally, the rarely analyzed SNP rs757343 (Tru9I) showed an overtransmission of the allele $\mathrm{G}$ (corresponding to "U") from parents to affected children as shown by Ramos-Lopez et al. 2006 and Boraska et al. $2008[38,46]$. Furthermore, in the study from Gyorffy et al. (2002) the haplotype "bau" was found more frequently in patients than in controls [26].

Furthermore, a variety of VDR allele combinations have been described as T1D protective $[21,24,38,48-50,63,69,70]$.

Interestingly, one of the lowest T1D incidence rates in Europe was described for the Greek island Crete: here, two haplotypes of the four VDR SNPs confer the highest risk (aBFT and aBFt) for T1D [50]. This underscores that an interplay of genetic and environmental factors modulates T1D susceptibility.

\subsection{Vitamin D Receptor and Meta-Analysis, Diabetes Complications and Monogenetic Vitamin D Disorders}

On the basis of the diverging results of VDR SNPs and T1D susceptibility, nine meta-analyses have been performed [75-83]. Eight out of nine meta-analyses on the VDR gene and T1D published between 2006 and 2017 agree on the conclusion that rs10735810 (FokI) and/or rs1544410 (BsmI) SNPs play an important role in the development of T1D [76-83] (Table 3). 
Table 3. Meta-analysis of VDR SNPs and T1D and diabetic nephropathy (DN).

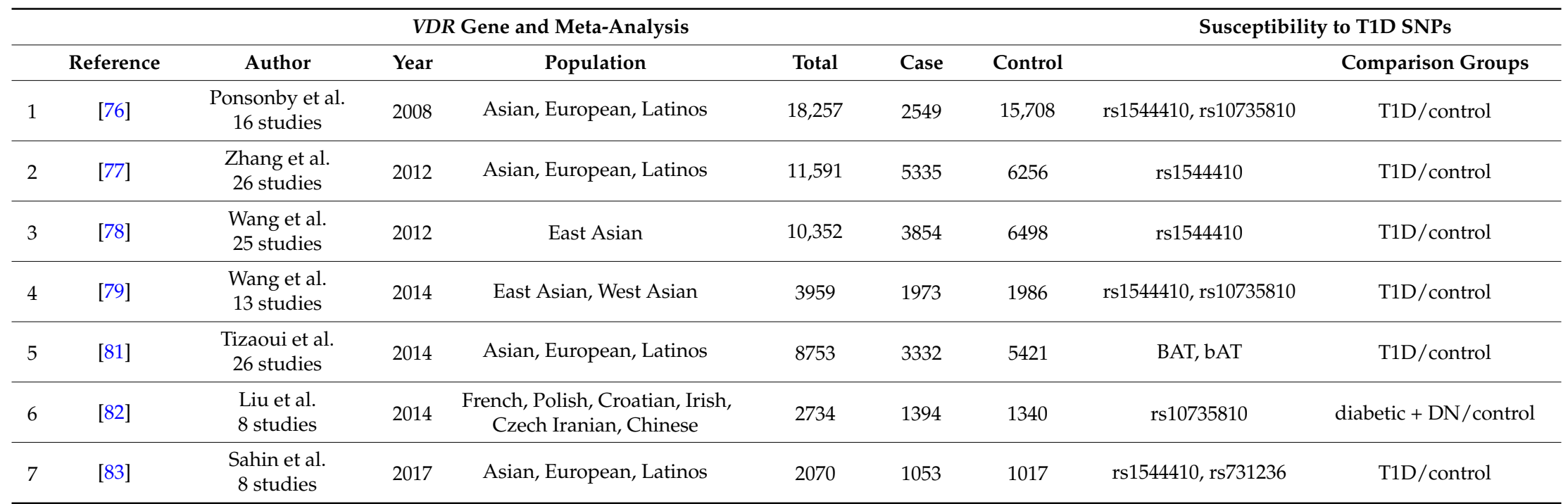

The meta-analysis published by Qin et al. [80] (23 studies, Asian, Latino, African and Caucasian) is not included in the Table because only an abstract was available. "B" allele of the rs154410 (=BsmI) SNP was associated with an increased risk for the development of T1D especially in Asians. rs10735810 (=FokI) and rs731236 (=TaqI). 
Ponsonby et al. (2008) [76] suggest that the association between the VDR SNPs and T1D should be seen as depending on the environment and not being responsible for T1D by itself. Therefore, the authors conducted a meta-analysis of 16 case-controlled studies from 19 regions and four additionally analyzed SNPs (rs7975232 ApaI, rs731236 TaqI, rs1544410 BsmI, and rs10735810 FokI) under the aspect of ambient winter UV radiation. The study centres were located across a range of latitudes from $33^{\circ} \mathrm{S}$ to $65^{\circ} \mathrm{N}$ corresponding to a winter $\mathrm{UV}$ radiation range from $1.0 \mathrm{~mW} / \mathrm{m}^{2}$ to $133.8 \mathrm{~mW} / \mathrm{m}^{2}$. The authors observed that the allele " $\mathrm{B}$ " of rs1544410 (BsmI) and the allele " $\mathrm{F}$ " of rs10735810 (FokI) were more likely risk factors for T1D under high-winter-UV radiation exposures. Four years later, Zhang et al. (2012) [77] published a meta-analysis based upon 23 case-control studies covering Asians, European and Latino populations and evaluating the ethnic-specific effects for an association with T1D. The main inclusion criteria for this meta-analysis were publications in English or Chinese; available data for genotype distributions in cases and controls; the genotype distribution of the tested controls was in Hardy-Weinberg equilibrium (HWE). Hereby, the "BB" genotype of the rs1544410 (BsmI) SNP was associated with an increased risk for the development of T1D, especially in Asians. This finding was also confirmed in the meta-analysis from Wang et al. 2012 [78], where 3854 cases and 6498 controls were included and an increased T1D risk for the " $\mathrm{B}$ " allele a particularly in East Asian population was found. In another meta-analysis, Wang et al. (2014) [79] selected 13 case-control studies (1973 T1D and 1986 controls) from the Asian region and evaluated two VDR SNPs (rs1544410 BsmI and rs10735810 FokI). Interestingly, the regional stratification analysis indicates that the rs1544410 (BsmI) "B" allele conferred an enhanced T1D risk in East Asia but the rs10735810 (FokI) allele " $\mathrm{F}$ " in the West Asian population. An additional meta-analysis covering the four VDR SNPs in Asian, European and Latino populations concluded that "BAT" was a significant T1D risk factor [81]. Furthermore, a recent meta-analysis on the basis of nine studies comprising 1053 children with T1D (Asian, European and Latino origin) confirmed the "BB" genotype of rs1544410 (BsmI) as risk marker for T1D and also for the " $\mathrm{tt}$ " genotype of the rs731236 (TaqI) SNP [83].

Liu et al. (2014) focused on the diabetes complications (diabetic nephropathy (DN) and diabetic retinopathy (DR)) and studied four variants of the VDR [82]. Hereby, the rs10735810 (FokI) SNP was associated with nephropathy risk in Caucasian diabetes patients, represented in a dominant model.

Apart from association studies, there are also informative case reports on genetic vitamin $D$ disorders in T1D. One case report describes the development of T1D in a child with pre-existing hereditary vitamin D-resistent rickets (VDRR) due to a compound heterozygous mutation of the VDR (L263R and R391S) that led to dissociated responses of the CYP24A1 and RELB promoters to 1,25-Dihydroxyvitamin $\mathrm{D}_{3}$ action [84]. Another case of VDRR was reported from India, where a 10-year-old girl had developed T1D [85]. An additional case report with an inborn error of vitamin D metabolism was published recently. A new missense mutation of the PHEX gene has been described in a T1D patient from a Han Chinese pedigree over four generations that caused X-linked hypophosphatemic rickets manifesting with renal phosphate wasting, a bone mineralisation and vitamin D metabolism defect [86].

These experiments of nature underline that a vitamin $\mathrm{D}$ defect syndrome may have the potential for additional disease such as $\beta$-cell autoimmunity resulting in T1D. A systematic investigation of the acquired and the innate immune system in fifteen patients with VDRR showed some impairments of the innate immunity, particularly lower cathelicidin production and a proinflammatory cytokine profile of lymphocytes [87]. This illustrates the enormous plasticity of the immune system adapting to a genetic defect and that only few patients with hereditary vitamin D defect syndromes will develop an autoimmune disease such as T1D.

\subsection{Other Vitamin D Metabolism Components}

Numerous studies focused on VDR SNPs but only few on other genes of the vitamin D pathway $[56,57,67,74,88-99]$. Table 4 presents a summary of association studies for SNPs within the genes CYP2R1 [57,88], CYP27B1 [57,90,91,93], DBP [96,97] as well as cubilin [99] and T1D. 
Table 4. T1D and a summary of association studies for SNPs within the genes CYP2R1, CYP27B1, DBP and cubilin.

\begin{tabular}{|c|c|c|c|c|c|c|c|}
\hline \multicolumn{6}{|c|}{ Other Vitamin D System Components } & \multicolumn{2}{|c|}{ Susceptibility to T1D SNPs } \\
\hline Author & Year & Population & Total & Case & Control & & Comparison Groups \\
\hline \multicolumn{8}{|c|}{ CYP2R1 gene } \\
\hline \multirow{2}{*}{ Ramos-Lopez et al. [88] } & \multirow{2}{*}{2007} & \multirow{2}{*}{ German } & 203 & & & rs10741657 & T1D families \\
\hline & & & 578 & 284 & 294 & rs10741657 & T1D/control \\
\hline \multirow{2}{*}{ Cooper et al. [57] } & \multirow{2}{*}{2011} & \multirow{2}{*}{ British } & 1933 & & & rs10741657, rs12794714 & T1D families \\
\hline & & & 18,955 & 8517 & 10,438 & rs10741657, rs12794714 & T1D/control \\
\hline \multicolumn{8}{|c|}{ CYP27B1 gene } \\
\hline Ramos-Lopez et al. [90] & 2004 & German & 572 & 252 & 320 & rs10877012 & T1D/control \\
\hline \multirow{3}{*}{ Bailey et al. [91] } & \multirow{3}{*}{2007} & Great Britain, Northern Ireland, & 2774 & & & rs10877012, rs4646536 & T1D families \\
\hline & & Finland, USA, Norway, Romania & & & & & \\
\hline & & Great Britain & 16,612 & 7854 & 8758 & rs10877012, rs4646536 & T1D/control \\
\hline \multirow{2}{*}{ Cooper et al. [57] } & \multirow{2}{*}{2011} & \multirow{2}{*}{ British } & 1933 & & & rs10877012 & T1D families \\
\hline & & & 18,955 & 8517 & 10,438 & rs10877012 & T1D/control \\
\hline Hussei et al. [93] & 2012 & Egyptian & 240 & 120 & 120 & rs10877012 & T1D/control \\
\hline \multicolumn{8}{|c|}{$D B P(G C)$ gene } \\
\hline Ongagna et al. [96] & 2001 & \multirow{2}{*}{ Alsatian and North African origin } & 95 & 43 & 52 & rs7041 & T1D/control \\
\hline Ongagna et al. [97] & 2005 & & 178 & 110 & 68 & rs7041 & T1D/control \\
\hline \multicolumn{8}{|c|}{ Cubilin gene } \\
\hline Ramos-Lopez et al. [99] & 2010 & German & 400 & 200 & 200 & rs3740165 & T1D/control \\
\hline
\end{tabular}


The vitamin D metabolising enzymes are all members of the cytochrome P450 superfamily of enzymes. These enzymes reside in mitochondria and contribute to the vitamin D synthesis (CYP2R1 and CYP27B1) and vitamin D degradation (CYP24A1). CYP27A1, CYP2D6, CYP2R1, CYP2C11, CYP3A4, CYP2D25 and CYP2J3 all belong to the group of hepatic cytochrome P450 enzymes with 25-hydroxylase activity. The key enzyme for the synthesis of $25(\mathrm{OH}) \mathrm{D}_{3}$ is CYP2R1 [100]. A mutation in exon 2 of the CYP2R1 gene can abolish the 25-hydroxylase activity resulting in severe vitamin $\mathrm{D}$ deficiency and a rare form of rickets [101].

The CYP2R1 gene is located on chromosome 11p15.2 with a length of $15 \mathrm{~kb}$ and contains five exons separated by four introns. Two SNPs (rs10741657 and rs12794714) were investigated in T1D [102]. The SNP rs10741657 (G/C) maps to a $2 \mathrm{~kb}$ mRNA transcript and rs12794714 (C $\rightarrow \mathrm{T}$, Ser $\rightarrow$ Ser) is a synonymous SNP in exon 2. Our investigations revealed that the allele G of the CYP2R1 rs10741657 SNP is more often transmitted to T1D affected offspring. Additionally, the case-control analysis shows a higher frequency of the GG genotype in T1D patients. The latter correlated with a lower $25(\mathrm{OH}) \mathrm{D}_{3}$ concentration [Ramos-Lopez et al. 2007] [88]. The subsequent analysis of a large number of samples from case/control $(n=8517 / 10,438)$ and T1D families $(n=1933)$ in the British population revealed an association between the two SNPs (rs10741657 and rs12794714) with T1D in a combined dataset [57].

The next enzyme in the vitamin D cascade, CYP27B1, is coded by a gene situated on chromosome 12p13.1-q13.3. The gene contains nine exons and eight introns and extends over $4.8 \mathrm{~kb}$. Mutations in the CYP27B1 gene can lead to an inactive protein unable to bind $25(\mathrm{OH}) \mathrm{D}_{3}$ as found in vitamin D dependent rickets [103]. Two SNPs within the CYP27B1 were investigated in relation to T1D, rs10877012 SNP (-1260 C/A) located in the promoter region and the rs4646536 SNP $(+2838 \mathrm{C} / \mathrm{T})$ in intron 6.

We originally observed that allele " $\mathrm{C}$ " and genotype "CC" were more frequent in patients with T1D than in controls [90]. Later studies, one from Egypt with 240 subjects and another one with a large collective (population different countries: British, Finland, USA, Norway, Romania) confirmed these findings [91,93]. Additionally, Bailey et al. (2007) showed also an association of T1D with the rs4646536 SNP. Cooper et al. (2011) confirmed the protective effect of the allele " $\mathrm{A}$ " of the rs10877012 SNP [57,91].

The last enzyme in the vitamin D cascade, CYP24A1 is capable of hydroxylating both metabolites $\left(25(\mathrm{OH}) \mathrm{D}_{3}\right.$, and $\left.1,25(\mathrm{OH})_{2} \mathrm{D}_{3}\right)$. However, the preferred substrate is $1,25(\mathrm{OH})_{2} \mathrm{D}_{3}$. CYP24A1 catabolizes $1,25(\mathrm{OH})_{2} \mathrm{D}_{3}$ in a complex of steps resulting in the production of water-soluble calcitroic acid [104]. Major alterations in the enzymatic activity of CYP24A1 can be due to mutations of the CYP24A1 gene located on chromosome 20p13 (20.5 kb, 12 exons) that cause idiopathic infantile hypercalcemia [105]. The CYP24A1 gene was investigated in relation to T1D susceptibility: sixteen tag SNPs for CYP24A1 that were analyzed by Bailey et al. (2007) [91] as well as two further SNPs (rs6013897 and rs2296241) did not show any association with T1D $[57,89]$. This gene is of potential clinical relevance because an undiagnosed CYP24A1 mutation may cause hypercalcemia also in adults if these are exposed to high vitamin D dosages.

A further essential component of the vitamin D system is the DBP, also called group-specific component (GC) that belongs to the proteins of the albumin family and transports vitamin $\mathrm{D}$ in the circulation. DBP is a single chain glycoprotein with a molecular weight of $52 \mathrm{kDa}$, predominantly synthesized in the liver. The DBP gene maps to chromosome 4q11-q13 and contains 13 exons and 12 introns and extends over $42.5 \mathrm{~kb}$. Among the many characterized DBP variants, two known SNPs in exon 11 were investigated for T1D susceptibility (rs7041 and rs4588). While the rs7041 SNP results in a $\mathrm{T}$ to $\mathrm{G}$ substitution (Aps to Glu in codon 416), rs4588 SNP leads to a $\mathrm{C}$ to $\mathrm{G}$ substitution (threonine to lysine in codon 420). The majority of the studies including the SNPs rs4588 and rs7041 and rs2282679 SNP failed to prove an association with T1D $[57,67,89,94,95,98]$. Two studies, however, originating from the same laboratory showed an association with rs7041 SNP and T1D [96,97]. Nevertheless, it has to be pointed out that several DBP/GC combinations of SNPs are conserved in the population forming a diverse profile of haplotypes. Such DBP haplotypes give rise to low or high affinity DBP/GC protein 
structures with a different binding of the free vitamin D metabolite and also affecting the monocyte production of cathelicidin [106].

Another molecule with a crucial role in vitamin D trafficking is cubilin. This $460-\mathrm{kDa}$ long protein is mainly localized in the proximal renal tubule, but has been identified in other tissues including placenta, intestinal epithelium among others.

A crucial role of cubilin is the formation of an endocytic receptor complex with megalin. That complex is capable of binding $\mathrm{DBP} / 25(\mathrm{OH}) \mathrm{D}_{3}$ with high affinity, mediating its uptake into the cells. The loss of functional cubilin in patients leads to loss of the $25(\mathrm{OH}) \mathrm{D}_{3}$ in urine and subsequent decrease in vitamin D metabolites plasma levels. Hence, our group examined SNPs within the cubilin gene as potential risk markers for T1D [99]. The cubilin gene is located on chromosome 10p12.33-p13. We analysed five cubilin SNPs (rs3740168, rs3740165, rs1801233, rs1801229 and rs2796835) in a case-control study (200 T1D and 200 controls). Out of these, the rs3740165 SNP was found to be associated with increased T1D risk. The genotype "AA" of the rs3740165 was more prevalent in T1D patients than in control but without correlation neither with $25(\mathrm{OH}) \mathrm{D}_{3}$, nor with $1,25(\mathrm{OH})_{2} \mathrm{D}_{3}$ concentration. It has to be pointed out that the SNP does not change the coding sequence in this position (Pro $\rightarrow$ Pro). Therefore, functional susceptibility may develop by a linked gene variant or a regulatory SNP.

\subsection{Major Susceptibility to Type 1 Diabetes by HLA and Other Immune Genes: Vitamin D}

The strongest susceptibility to type 1 diabetes is conferred by high risk HLA DR-DQ alleles present as hetero- or homozygous combinations most patients. There are up to 40 additional risk loci identified and some of them have been shown to affect lymphoid enhancer sequence in T and B cells, thymus and CD34 ${ }^{+}$stem cells [107]. Vitamin D regulates several immune genes as identified through genome wide studies by VDR chromatin immunoprecipitation followed by mass DNA sequencing (CHIP-seq) $[108,109]$ where VDR binding to autoimmune susceptibility loci was identified amongst them type 1 diabetes sites. Hereby, the VDR-enhanced susceptibility to T1D may form a genetically determined proinflammatory cytokine pattern [110].

\subsection{Vitamin D Intervention in Type 1 Diabetes and Pharmacogenomics}

Vitamin D deficiency is a worldwide problem [111]. It enhances the risk for various conditions including T1D [112] and provides the rationale for many intervention trials (clincaltrials.gov currently-as of 11 April 2017-3122 trials listed). The potential to modify the development of T1D was reported in a case-control study and a birth cohort follow-up study from Finland: it strongly indicated that vitamin D supplementation in infancy decreases the risk of T1D $[113,114]$. The therapeutic benefit of vitamin D onT1D was tested in some clinical trials [2] but only few studies examined the effect of the vitamin D SNPs in the context of vitamin D supplementation for T1D [115-117]. We recently performed a randomized, double-blind, placebo-controlled trial with cross-over design in which thirty-nine patients with T1D received $4000 \mathrm{IU} /$ day cholecalciferol for three months followed by placebo or in reverse sequence. Hereby, besides an improvement of the vitamin D status (median $25(\mathrm{OH}) \mathrm{D}_{3}$ increased to $38 \mathrm{ng} / \mathrm{mL}$ ), the regulatory T cells (Treg) demonstrated a differential response to vitamin D to three months' treatment according to VDR SNPs. Furthermore, this trial also showed an improvement of glycemic parameters under vitamin D treatment. Patients carrying the genotypes aa, TT and bb (rs7975232 ApaI, rs731236 TaqI and rs1544410 BsmI) were capable of raising their Treg cell number [115]. A further study tested in vitro the functional role of the VDR rs10735810 (FokI) SNP in T-helper $\left(\mathrm{CD}^{+} \mathrm{CD}^{+}\right)$from twenty patients with T1D. The stimulation of $\mathrm{CD}^{+} \mathrm{CD}^{+}$cells with $25(\mathrm{OH}) \mathrm{D}_{3}[62.4 \mathrm{nM}]$ and $1,25(\mathrm{OH})_{2} \mathrm{D}_{3}\left[1 \times 10^{-8} \mathrm{M}\right]$ for $72 \mathrm{~h}$ revealed a reduced percentage

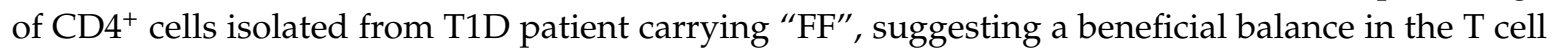
compartment [116].

In a prior in vitro study, Mauf et al. (2015) [117] had explored the immunomodulatory effects of vitamin D supplementation on $25(\mathrm{OH}) \mathrm{D}_{3}$ levels, on dendritic cells in twelve patients with $\mathrm{T} 1 \mathrm{D}$ 
and the role of the vitamin D SNPs. Remarkably, the $25(\mathrm{OH}) \mathrm{D}_{3}$ treatment $(50 \mathrm{ng} / \mathrm{mL})$ for seven days inhibited the differentiation of monocytes into dendritic cells, promoting the formation of intermediate cells (IC). The increase of IC under supplementation with $25(\mathrm{OH}) \mathrm{D}_{3}$ was related to the genotypes of two VDR SNPs (rs731236 TaqI and rs1544410 BsmI) and one SNP of the CYP24A1 gene (rs927650), illustrating that the immune effects of vitamin $D$ supplementation can depend on genetic variants of the vitamin D system.

\section{Conclusions}

Vitamin D deficiency is a risk factor for T1D and genes of the vitamin D system show robust associations with T1D. The vitamin D system appears to affect the immune regulatory pathways, leading to the final $\beta$-cell destruction. Several experimental lines of evidence suggest islet protection by vitamin D. Exploiting this potential will be a challenge for future studies, including larger controlled trials with different doses of vitamin D and functional studies to elucidate mechanistic actions in the immune system and also for metabolic end points.

Acknowledgments: We thank Anna U. Kraus and Nojan Nejatian for their help in the literature screening. The research has been supported by the Else Kröner-Fresenius Foundation (EKFS) and the German Diabetes Society.

Conflicts of Interest: The Authors declare no conflict of interest.

\section{References}

1. Rewers, M.; Ludvigsson, J. Environmental risk factors for type 1 diabetes. Lancet 2016, 387, 2340-2348. [CrossRef]

2. Mathieu, C. Vitamin D and diabetes: Where do we stand? Diabetes Res. Clin. Pract. 2015, 108, $201-209$. [CrossRef] [PubMed]

3. Riachy, R.; Vandewalle, B.; Belaich, S.; Kerr-Conte, J.; Gmyr, V.; Zerimech, F.; d'Herbomez, M.; Lefebvre, J.; Pattou, F. Beneficial effect of 1,25 dihydroxyvitamin $\mathrm{D}_{3}$ on cytokine-treated human pancreatic islets. J. Endocrinol. 2001, 169, 161-168. [CrossRef] [PubMed]

4. Van Belle, T.L.; Vanherwegen, A.S.; Feyaerts, D.; De Clercq, P.; Verstuyf, A.; Korf, H.; Gysemans, C.; Mathieu, C. 1,25-dihydroxyvitamin $\mathrm{D}_{3}$ and its analog TX527 promote a stable regulatory $\mathrm{T}$ cell phenotype in T cells from type 1 diabetes patients. PLoS ONE 2014, 9, e109194. [CrossRef] [PubMed]

5. Ferreira, G.B.; Gysemans, C.A.; Demengeot, J.; da Cunha, J.P.; Vanherwegen, A.S.; Overbergh, L.; Van Belle, T.L.; Pauwels, F.; Verstuyf, A.; Korf, H.; et al. 1,25-dihydroxyvitamin $\mathrm{D}_{3}$ promotes tolerogenic dendritic cells with functional migratory properties in nod mice. J. Immunol. 2014, 192, 4210-4220. [CrossRef] [PubMed]

6. Holick, M.F.; Chen, T.C.; Lu, Z.; Sauter, E. Vitamin D and skin physiology: A d-lightful story. J. Bone Miner. Res. 2007, 22, V28-V33. [CrossRef] [PubMed]

7. Fraser, D.R.; Kodicek, E. Unique biosynthesis by kidney of a biological active vitamin D metabolite. Nature 1970, 228, 764-766. [CrossRef] [PubMed]

8. Kliewer, S.A.; Umesono, K.; Noonan, D.J.; Heyman, R.A.; Evans, R.M. Convergence of 9-cis retinoic acid and peroxisome proliferator signalling pathways through heterodimer formation of their receptors. Nature 1992, 358, 771-774. [CrossRef] [PubMed]

9. Carlberg, C.; Campbell, M.J. Vitamin D receptor signaling mechanisms: Integrated actions of a well-defined transcription factor. Steroids 2013, 78, 127-136. [CrossRef] [PubMed]

10. Rowling, M.J.; Kemmis, C.M.; Taffany, D.A.; Welsh, J. Megalin-mediated endocytosis of vitamin D binding protein correlates with 25-hydroxycholecalciferol actions in human mammary cells. J. Nutr. 2006, 136, 2754-2759. [PubMed]

11. Veldman, C.M.; Cantorna, M.T.; DeLuca, H.F. Expression of 1,25-dihydroxyvitamin $\mathrm{D}_{3}$ receptor in the immune system. Arch. Biochem. Biophys. 2000, 374, 334-338. [CrossRef] [PubMed]

12. Verstuyf, A.; Carmeliet, G.; Bouillon, R.; Mathieu, C. Vitamin D: A pleiotropic hormone. Kidney Int. 2010, 78, 140-145. [CrossRef] [PubMed]

13. Zehnder, D.; Bland, R.; Williams, M.C.; McNinch, R.W.; Howie, A.J.; Stewart, P.M.; Hewison, M. Extrarenal expression of 25-hydroxyvitamin $\mathrm{D}_{3}-1$ alpha-hydroxylase. J. Clin. Endocrinol. Metab. 2001, 86, 888-894. [PubMed] 
14. Pike, J.W.; Meyer, M.B. The vitamin d receptor: New paradigms for the regulation of gene expression by 1,25-dihydroxyvitamin $\mathrm{D}_{3}$. Endocrinol. Metab. Clin. N. Am. 2010, 39, 255-269. [CrossRef] [PubMed]

15. Miyamoto, K.; Kesterson, R.A.; Yamamoto, H.; Taketani, Y.; Nishiwaki, E.; Tatsumi, S.; Inoue, Y.; Morita, K.; Takeda, E.; Pike, J.W. Structural organization of the human vitamin d receptor chromosomal gene and its promoter. Mol. Endocrinol. 1997, 11, 1165-1179. [CrossRef] [PubMed]

16. Morrison, N.A.; Yeoman, R.; Kelly, P.J.; Eisman, J.A. Contribution of trans-acting factor alleles to normal physiological variability: Vitamin D receptor gene polymorphism and circulating osteocalcin. Proc. Natl. Acad. Sci. USA 1992, 89, 6665-6669. [CrossRef] [PubMed]

17. Arai, H.; Miyamoto, K.; Taketani, Y.; Yamamoto, H.; Iemori, Y.; Morita, K.; Tonai, T.; Nishisho, T.; Mori, S.; Takeda, E. A vitamin D receptor gene polymorphism in the translation initiation codon: Effect on protein activity and relation to bone mineral density in Japanese women. J. Bone Miner. Res. 1997, 12, 915-921. [CrossRef] [PubMed]

18. Jurutka, P.W.; Remus, L.S.; Whitfield, G.K.; Thompson, P.D.; Hsieh, J.C.; Zitzer, H.; Tavakkoli, P.; Galligan, M.A.; Dang, H.T.; Haussler, C.A.; et al. The polymorphic $\mathrm{n}$ terminus in human vitamin d receptor isoforms influences transcriptional activity by modulating interaction with transcription factor iib. Mol. Endocrinol. 2000, 14, 401-420. [CrossRef] [PubMed]

19. McDermott, M.F.; Ramachandran, A.; Ogunkolade, B.W.; Aganna, E.; Curtis, D.; Boucher, B.J.; Snehalatha, C.; Hitman, G.A. Allelic variation in the vitamin D receptor influences susceptibility to iddm in Indian Asians. Diabetologia 1997, 40, 971-975. [CrossRef] [PubMed]

20. Hauache, O.M.; Lazaretti-Castro, M.; Andreoni, S.; Gimeno, S.G.; Brandao, C.; Ramalho, A.C.; Kasamatsu, T.S.; Kunii, I.; Hayashi, L.F.; Dib, S.A.; et al. Vitamin D receptor gene polymorphism: Correlation with bone mineral density in a Brazilian population with insulin-dependent diabetes mellitus. Osteoporos. Int. 1998, 8, 204-210. [CrossRef] [PubMed]

21. Pani, M.A.; Knapp, M.; Donner, H.; Braun, J.; Baur, M.P.; Usadel, K.H.; Badenhoop, K. Vitamin D receptor allele combinations influence genetic susceptibility to type 1 diabetes in Germans. Diabetes 2000, 49, 504-507. [CrossRef] [PubMed]

22. Chang, T.J.; Lei, H.H.; Yeh, J.I.; Chiu, K.C.; Lee, K.C.; Chen, M.C.; Tai, T.Y.; Chuang, L.M. Vitamin d receptor gene polymorphisms influence susceptibility to type 1 diabetes mellitus in the Taiwanese population. Clin. Endocrinol. 2000, 52, 575-580. [CrossRef]

23. Ban, Y.; Taniyama, M.; Yanagawa, T.; Yamada, S.; Maruyama, T.; Kasuga, A.; Ban, Y. Vitamin D receptor initiation codon polymorphism influences genetic susceptibility to type 1 diabetes mellitus in the Japanese population. BMC Med. Genet. 2001. [CrossRef]

24. Guja, C.; Marshall, S.; Welsh, K.; Merriman, M.; Smith, A.; Todd, J.A.; Ionescu-Tirgoviste, C. The study of ctla-4 and vitamin D receptor polymorphisms in the Romanian type 1 diabetes population. J. Cell. Mol. Med. 2002, 6, 75-81. [CrossRef] [PubMed]

25. Yokota, I.; Satomura, S.; Kitamura, S.; Taki, Y.; Naito, E.; Ito, M.; Nisisho, K.; Kuroda, Y. Association between vitamin D receptor genotype and age of onset in juvenile Japanese patients with type 1 diabetes. Diabetes Care 2002, 25, 1244. [CrossRef] [PubMed]

26. Gyorffy, B.; Vasarhelyi, B.; Krikovszky, D.; Madacsy, L.; Tordai, A.; Tulassay, T.; Szabo, A. Gender-specific association of vitamin D receptor polymorphism combinations with type 1 diabetes mellitus. Eur. J. Endocrinol. 2002, 147, 803-808. [CrossRef] [PubMed]

27. Fassbender, W.J.; Goertz, B.; Weismuller, K.; Steinhauer, B.; Stracke, H.; Auch, D.; Linn, T.; Bretzel, R.G. $V D R$ gene polymorphisms are overrepresented in german patients with type 1 diabetes compared to healthy controls without effect on biochemical parameters of bone metabolism. Horm. Metab. Res. 2002, 34, 330-337. [CrossRef] [PubMed]

28. Taverna, M.J.; Sola, A.; Guyot-Argenton, C.; Pacher, N.; Bruzzo, F.; Slama, G.; Reach, G.; Selam, J.L. Taq I polymorphism of the vitamin D receptor and risk of severe diabetic retinopathy. Diabetologia 2002, 45, 436-442. [CrossRef] [PubMed]

29. Skrabic, V.; Zemunik, T.; Situm, M.; Terzic, J. Vitamin D receptor polymorphism and susceptibility to type 1 diabetes in the Dalmatian population. Diabetes Res. Clin. Pract. 2003, 59, 31-35. [CrossRef]

30. Motohashi, Y.; Yamada, S.; Yanagawa, T.; Maruyama, T.; Suzuki, R.; Niino, M.; Fukazawa, T.; Kasuga, A.; Hirose, H.; Matsubara, K.; et al. Vitamin D receptor gene polymorphism affects onset pattern of type 1 diabetes. J. Clin. Endocrinol. Metab. 2003, 88, 3137-3140. [CrossRef] [PubMed] 
31. Turpeinen, H.; Hermann, R.; Vaara, S.; Laine, A.P.; Simell, O.; Knip, M.; Veijola, R.; Ilonen, J. Vitamin D receptor polymorphisms: No association with type 1 diabetes in the Finnish population. Eur. J. Endocrinol. 2003, 149, 591-596. [CrossRef] [PubMed]

32. Nejentsev, S.; Cooper, J.D.; Godfrey, L.; Howson, J.M.; Rance, H.; Nutland, S.; Walker, N.M.; Guja, C.; Ionescu-Tirgoviste, C.; Savage, D.A.; et al. Analysis of the vitamin D receptor gene sequence variants in type 1 diabetes. Diabetes 2004, 53, 2709-2712. [CrossRef] [PubMed]

33. Bianco, M.G.; Minicucci, L.; Calevo, M.G.; Lorini, R. Vitamin D receptor polymorphisms: Are they really associated with type 1 diabetes? Eur. J. Endocrinol. 2004, 151, 641-642. [CrossRef] [PubMed]

34. Audi, L.; Marti, G.; Esteban, C.; Oyarzabal, M.; Chueca, M.; Gussinye, M.; Yeste, D.; Fernandez-Cancio, M.; Andaluz, P.; Carrascosa, A. VDR gene polymorphism at exon 2 start codon (FOKI) may have influenced type 1 diabetes mellitus susceptibility in two Spanish populations. Diabetic Med. 2004, 21, 393-394. [CrossRef] [PubMed]

35. Zemunik, T.; Škrabić, V.; Boraska, V.; Diklić, D.; Terzić, I.M.; Čapkun, V.; Peruzović, M.; Terzić, J. Foki polymorphism, vitamin D receptor, and interleukin-1 receptor haplotypes are associated with type 1 diabetes in the Dalmatian population. J. Mol. Diagn. 2005, 7, 600-604. [CrossRef]

36. San-Pedro, J.I.; Bilbao, J.R.; Perez de Nanclares, G.; Vitoria, J.C.; Martul, P.; Castano, L. Heterogeneity of vitamin D receptor gene association with celiac disease and type 1 diabetes mellitus. Autoimmunity 2005, 38, 439-444. [CrossRef] [PubMed]

37. Taverna, M.J.; Selam, J.L.; Slama, G. Association between a protein polymorphism in the start codon of the vitamin D receptor gene and severe diabetic retinopathy in c-peptide-negative type 1 diabetes. J. Clin. Endocrinol. Metab. 2005, 90, 4803-4808. [CrossRef] [PubMed]

38. Ramos-Lopez, E.; Jansen, T.; Ivaskevicius, V.; Kahles, H.; Klepzig, C.; Oldenburg, J.; Badenhoop, K. Protection from type 1 diabetes by vitamin D receptor haplotypes. Ann. N. Y. Acad. Sci. 2006, 1079, 327-334. [CrossRef] [PubMed]

39. Kanazawa, Y.; Motohashi, Y.; Yamada, S.; Oikawa, Y.; Shigihara, T.; Okubo, Y.; Maruyama, T.; Shimada, A. Frequency of ctla- 4 gene ct60 polymorphism may not be affected by vitamin D receptor gene BSM I polymorphism or HLA DR9 in autoimmune-related type 1 diabetes in the Japanese. Ann. N. Y. Acad. Sci. 2006, 1079, 251-256. [CrossRef] [PubMed]

40. Xiao, X.H.; Liu, Z.L.; Wang, H.; Sun, Q.; Li, W.H.; Yang, G.H.; Liu, Q.Y. Effects of vitamin D receptor gene polymorphisms on susceptibility to type 1 diabetes mellitus. Chin. Med. Sci. J. 2006, 21, 95-98. [PubMed]

41. Capoluongo, E.; Pitocco, D.; Concolino, P.; Santonocito, C.; Di Stasio, E.; d'Onofrio, G.; Manto, A.; Giardina, B.; Ghirlanda, G.; Ameglio, F.; et al. Slight association between type 1 diabetes and "FF" VDR FOKI genotype in patients from the Italian Lazio region. Lack of association with diabetes complications. Clin. Biochem. 2006, 39, 888-892. [CrossRef] [PubMed]

42. Mimbacas, A.; Trujillo, J.; Gascue, C.; Javiel, G.; Cardoso, H. Prevalence of vitamin D receptor gene polymorphism in a uruguayan population and its relation to type 1 diabetes mellitus. Genet. Mol. Res. 2007, 6, 534-542. [PubMed]

43. Garcia, D.; Angel, B.; Carrasco, E.; Albala, C.; Santos, J.L.; Perez-Bravo, F. Vdr polymorphisms influence the immune response in type 1 diabetic children from Santiago, Chile. Diabetes Res. Clin. Pract. 2007, 77, 134-140. [CrossRef] [PubMed]

44. Shimada, A.; Kanazawa, Y.; Motohashi, Y.; Yamada, S.; Maruyama, T.; Ikegami, H.; Awata, T.; Kawasaki, E.; Kobayashi, T.; Nakanishi, K.; et al. Evidence for association between vitamin D receptor Bsmi polymorphism and type 1 diabetes in Japanese. J. Autoimmun. 2008, 30, 207-211. [CrossRef] [PubMed]

45. Lemos, M.C.; Fagulha, A.; Coutinho, E.; Gomes, L.; Bastos, M.; Barros, L.; Carrilho, F.; Geraldes, E.; Regateiro, F.J.; Carvalheiro, M. Lack of association of vitamin D receptor gene polymorphisms with susceptibility to type 1 diabetes mellitus in the Portuguese population. Hum. Immunol. 2008, 69, 134-138. [CrossRef] [PubMed]

46. Boraska, V.; Skrabic, V.; Zeggini, E.; Groves, C.J.; Buljubasic, M.; Peruzovic, M.; Zemunik, T. Family-based analysis of vitamin d receptor gene polymorphisms and type 1 diabetes in the population of South Croatia. J. Hum. Genet. 2008, 53, 210-214. [CrossRef] [PubMed]

47. Lopez, T.; Garcia, D.; Angel, B.; Carrasco, E.; Codner, E.; Ugarte, F.; Perez-Bravo, F. Association between fok I vitamin D receptor (VDR) gene polymorphism and plasmatic concentrations of transforming growth factor-beta1 and interferon gamma in type 1 diabetes mellitus. Med. Clin. 2008, 130, 81-84. [CrossRef] 
48. Mory, D.B.; Rocco, E.R.; Miranda, W.L.; Kasamatsu, T.; Crispim, F.; Dib, S.A. Prevalence of vitamin D receptor gene polymorphisms Foki and Bsmi in Brazilian individuals with type 1 diabetes and their relation to beta-cell autoimmunity and to remaining beta-cell function. Hum. Immunol. 2009, 70, 447-451. [CrossRef] [PubMed]

49. Panierakis, C.; Goulielmos, G.; Mamoulakis, D.; Maraki, S.; Papavasiliou, E.; Galanakis, E. Staphylococcus aureus nasal carriage might be associated with vitamin $\mathrm{D}$ receptor polymorphisms in type 1 diabetes. Int. J. Infect. Dis. 2009, 13, e437-e443. [CrossRef] [PubMed]

50. Panierakis, C.; Goulielmos, G.; Mamoulakis, D.; Petraki, E.; Papavasiliou, E.; Galanakis, E. Vitamin D receptor gene polymorphisms and susceptibility to type 1 diabetes in Crete, Greece. Clin. Immunol. 2009, 133, 276-281. [CrossRef] [PubMed]

51. Howson, J.M.; Walker, N.M.; Smyth, D.J.; Todd, J.A. Analysis of 19 genes for association with type I diabetes in the type I diabetes genetics consortium families. Genes Immun. 2009, 10, S74-S84. [CrossRef] [PubMed]

52. Israni, N.; Goswami, R.; Kumar, A.; Rani, R. Interaction of vitamin D receptor with HLA DRB1 0301 in type 1 diabetes patients from North India. PLoS ONE 2009, 4, e8023. [CrossRef] [PubMed]

53. Bucan, K.; Ivanisevic, M.; Zemunik, T.; Boraska, V.; Skrabic, V.; Vatavuk, Z.; Galetovic, D.; Znaor, L. Retinopathy and nephropathy in type 1 diabetic patients-Association with polymorphysms of vitamin D-receptor, tnf, neuro-D and IL-1 receptor 1 genes. Coll. Antropol. 2009, 33, 99-105. [PubMed]

54. Kahles, H.; Morahan, G.; Todd, J.A.; Badenhoop, K.; Type, I.D.G.C. Association analyses of the vitamin D receptor gene in 1654 families with type I diabetes. Genes Immun. 2009, 10, S60-S63. [CrossRef] [PubMed]

55. Kocabas, A.; Karaguzel, G.; Imir, N.; Yavuzer, U.; Akcurin, S. Effects of vitamin D receptor gene polymorphisms on susceptibility to disease and bone mineral density in turkish patients with type 1 diabetes mellitus. J. Pediatr. Endocrinol. Metab. 2010, 23, 1289-1297. [CrossRef] [PubMed]

56. Martin, R.J.; McKnight, A.J.; Patterson, C.C.; Sadlier, D.M.; Maxwell, A.P.; Warren, U.K.G.S.G. A rare haplotype of the vitamin D receptor gene is protective against diabetic nephropathy. Nephrol. Dial. Transplant. 2010, 25, 497-503. [CrossRef] [PubMed]

57. Cooper, J.D.; Smyth, D.J.; Walker, N.M.; Stevens, H.; Burren, O.S.; Wallace, C.; Greissl, C.; Ramos-Lopez, E.; Hypponen, E.; Dunger, D.B.; et al. Inherited variation in vitamin D genes is associated with predisposition to autoimmune disease type 1 diabetes. Diabetes 2011, 60, 1624-1631. [CrossRef] [PubMed]

58. Gogas Yavuz, D.; Keskin, L.; Kiyici, S.; Sert, M.; Yazici, D.; Sahin, I.; Yuksel, M.; Deyneli, O.; Aydin, H.; Tuncel, E.; et al. Vitamin d receptor gene Bsmi, Foki, Apai, Taqi polymorphisms and bone mineral density in a group of turkish type 1 diabetic patients. Acta Diabetol. 2011, 48, 329-336. [CrossRef] [PubMed]

59. Sahin, S.B.; Cetinkalp, S.; Erdogan, M.; Yilmaz, C.; Berdeli, A. Fas, fas ligand, and vitamin d receptor Foki gene polymorphisms in patients with type 1 diabetes mellitus in the Aegean Region of Turkey. Genet. Test Mol. Biomark. 2012, 16, 1179-1183. [CrossRef] [PubMed]

60. Mohammadnejad, Z.; Ghanbari, M.; Ganjali, R.; Afshari, J.T.; Heydarpour, M.; Taghavi, S.M.; Fatemi, S.; Rafatpanah, H. Association between vitamin D receptor gene polymorphisms and type 1 diabetes mellitus in Iranian population. Mol. Biol. Rep. 2012, 39, 831-837. [CrossRef] [PubMed]

61. Bonakdaran, S.; Abbaszadegan, M.R.; Dadkhah, E.; Khajeh-Dalouie, M. Vitamin D receptor gene polymorphisms in type 1 diabetes mellitus: A new pattern from khorasan province, islamic republic of Iran. East. Mediterr. Health J. 2012, 18, 614-619. [PubMed]

62. Vedralova, M.; Kotrbova-Kozak, A.; Zeleznikova, V.; Zoubkova, H.; Rychlik, I.; Cerna, M. Polymorphisms in the vitamin D receptor gene and parathyroid hormone gene in the development and progression of diabetes mellitus and its chronic complications, diabetic nephropathy and non-diabetic renal disease. Kidney Blood Press. Res. 2012, 36, 1-9. [CrossRef] [PubMed]

63. Frederiksen, B.; Liu, E.; Romanos, J.; Steck, A.K.; Yin, X.; Kroehl, M.; Fingerlin, T.E.; Erlich, H.; Eisenbarth, G.S.; Rewers, M.; et al. Investigation of the vitamin $\mathrm{d}$ receptor gene $(V D R)$ and its interaction with protein tyrosine phosphatase, non-receptor type 2 gene (PTPN2) on risk of islet autoimmunity and type 1 diabetes: The diabetes autoimmunity study in the young (daisy). J. Steroid Biochem. Mol. Biol. 2013, 133, 51-57. [CrossRef] [PubMed]

64. Hamed, E.O.; Abdel-Aal, A.M.; Din, A.K.; Atia, M.M. Vitamin D level and Fok-I vitamin D receptor gene polymorphism in Egyptian patients with type-1 diabetes. Egypt. J. Immunol. 2013, 20, 1-10. [PubMed] 
65. De Azevedo Silva, J.; Guimaraes, R.L.; Brandao, L.A.; Araujo, J.; Segat, L.; Crovella, S.; Sandrin-Garcia, P. Vitamin D receptor $(V D R)$ gene polymorphisms and age onset in type 1 diabetes mellitus. Autoimmunity 2013, 46, 382-387. [CrossRef] [PubMed]

66. Greer, R.M.; Portelli, S.L.; Hung, B.S.; Cleghorn, G.J.; McMahon, S.K.; Batch, J.A.; Conwell, L.S. Serum vitamin d levels are lower in Australian children and adolescents with type 1 diabetes than in children without diabetes. Pediatr. Diabetes 2013, 14, 31-41. [CrossRef] [PubMed]

67. Thorsen, S.U.; Mortensen, H.B.; Carstensen, B.; Fenger, M.; Thuesen, B.H.; Husemoen, L.; Bergholdt, R.; Brorsson, C.; Pociot, F.; Linneberg, A.; et al. No association between type 1 diabetes and genetic variation in vitamin D metabolism genes: A danish study. Pediatr. Diabetes 2014, 15, 416-421. [CrossRef] [PubMed]

68. Abd-Allah, S.H.; Pasha, H.F.; Hagrass, H.A.; Alghobashy, A.A. Vitamin d status and vitamin D receptor gene polymorphisms and susceptibility to type 1 diabetes in Egyptian children. Gene 2014, 536, 430-434. [CrossRef] [PubMed]

69. Kamel, M.M.; Fouad, S.A.; Salaheldin, O.; El-Razek Ael, R.; El-Fatah, A.I. Impact of vitamin D receptor gene polymorphisms in pathogenesis of type-1 diabetes mellitus. Int. J. Clin. Exp. Med. 2014, 7, 5505-5510. [PubMed]

70. Cheon, C.K.; Nam, H.K.; Lee, K.H.; Kim, S.Y.; Song, J.S.; Kim, C. Vitamin D receptor gene polymorphisms and type 1 diabetes mellitus in a Korean population. Pediatr. Int. 2015, 57, 870-874. [CrossRef] [PubMed]

71. Miettinen, M.E.; Smart, M.C.; Kinnunen, L.; Mathews, C.; Harjutsalo, V.; Surcel, H.M.; Lamberg-Allardt, C.; Tuomilehto, J.; Hitman, G.A. Maternal VDR variants rather than 25-hydroxyvitamin d concentration during early pregnancy are associated with type 1 diabetes in the offspring. Diabetologia 2015, 58, 2278-2283. [CrossRef] [PubMed]

72. Kahles, H.; Fain, P.R.; Baker, P.; Eisenbarth, G.; Badenhoop, K. Genetics of autoimmune thyroiditis in type 1 diabetes reveals a novel association with dpb1*0201: Data from the type 1 diabetes genetics consortium. Diabetes Care 2015, 38 (Suppl. 2), S21-S28. [CrossRef] [PubMed]

73. Mory, D.B.; Gabbay, M.A.; Rocco, E.R.; Kasamatsu, T.; Crispim, F.; Miranda, W.L.; Dib, S.A. High frequency of vitamin D receptor gene polymorphism foki in Brazilian type 1 diabetes mellitus patients with clinical autoimmune thyroid disease. Diabetol. Metab. Syndr. 2016. [CrossRef] [PubMed]

74. Sun, C.; Wei, H.; Chen, X.; Zhao, Z.; Du, H.; Song, W.; Yang, Y.; Zhang, M.; Lu, W.; Pei, Z.; et al. Erbb3-rs2292239 as primary type 1 diabetes association locus among non-hla genes in chinese. Meta Gene 2016, 9, 120-123. [CrossRef] [PubMed]

75. Guo, S.W.; Magnuson, V.L.; Schiller, J.J.; Wang, X.; Wu, Y.; Ghosh, S. Meta-analysis of vitamin d receptor polymorphisms and type 1 diabetes: A huge review of genetic association studies. Am. J. Epidemiol. 2006, 164, 711-724. [CrossRef] [PubMed]

76. Ponsonby, A.L.; Pezic, A.; Ellis, J.; Morley, R.; Cameron, F.; Carlin, J.; Dwyer, T. Variation in associations between allelic variants of the vitamin $\mathrm{D}$ receptor gene and onset of type 1 diabetes mellitus by ambient winter ultraviolet radiation levels: A meta-regression analysis. Am. J. Epidemiol. 2008, 168, 358-365. [CrossRef] [PubMed]

77. Zhang, J.; Li, W.; Liu, J.; Wu, W.; Ouyang, H.; Zhang, Q.; Wang, Y.; Liu, L.; Yang, R.; Liu, X.; et al. Polymorphisms in the vitamin $\mathrm{D}$ receptor gene and type 1 diabetes mellitus risk: An update by meta-analysis. Mol. Cell. Endocrinol. 2012, 355, 135-142. [CrossRef] [PubMed]

78. Wang, Q.; Xi, B.; Reilly, K.H.; Liu, M.; Fu, M. Quantitative assessment of the associations between four polymorphisms (Foki, Apai, Bsmi, Taqi) of vitamin d receptor gene and risk of diabetes mellitus. Mol. Biol. Rep. 2012, 39, 9405-9414. [CrossRef] [PubMed]

79. Wang, G.; Zhang, Q.; Xu, N.; Xu, K.; Wang, J.; He, W.; Yang, T. Associations between two polymorphisms (Foki and Bsmi) of vitamin D receptor gene and type 1 diabetes mellitus in Asian population: A meta-analysis. PLoS ONE 2014, 9, e89325. [CrossRef] [PubMed]

80. Qin, W.H.; Wang, H.X.; Qiu, J.L.; Huang, X.B.; Huang, Y.; Wu, N.R.; Liang, H.S. A meta-analysis of association of vitamin D receptor Bsmi gene polymorphism with the risk of type 1 diabetes mellitus. J. Recept. Signal Trans. Res. 2014, 34, 372-377. [CrossRef] [PubMed]

81. Tizaoui, K.; Kaabachi, W.; Hamzaoui, A.; Hamzaoui, K. Contribution of VDR polymorphisms to type 1 diabetes susceptibility: Systematic review of case-control studies and meta-analysis. J. Steroid Biochem. Mol. Biol. 2014, 143, 240-249. [CrossRef] [PubMed] 
82. Liu, Z.; Liu, L.; Chen, X.; He, W.; Yu, X. Associations study of vitamin d receptor gene polymorphisms with diabetic microvascular complications: A meta-analysis. Gene 2014, 546, 6-10. [CrossRef] [PubMed]

83. Sahin, O.A.; Goksen, D.; Ozpinar, A.; Serdar, M.; Onay, H. Association of vitamin D receptor polymorphisms and type 1 diabetes susceptibility in children: A meta-analysis. Endocr. Connect. 2017, 6, 159-171. [CrossRef] [PubMed]

84. Nguyen, M.; d'Alesio, A.; Pascussi, J.M.; Kumar, R.; Griffin, M.D.; Dong, X.; Guillozo, H.; Rizk-Rabin, M.; Sinding, C.; Bougneres, P.; et al. Vitamin d-resistant rickets and type 1 diabetes in a child with compound heterozygous mutations of the vitamin d receptor (1263r and r391s): Dissociated responses of the cyp-24 and rel-b promoters to 1,25-dihydroxyvitamin d3. J. Bone Miner. Res. 2006, 21, 886-894. [CrossRef] [PubMed]

85. Sarkar, S.; Mondal, R.; Banerjee, I.; Sabui, T. Type II vitamin D-dependent rickets with diabetic ketoacidosis. J. Pediatr. Endocrinol. Metab. 2013, 26, 941-943. [CrossRef] [PubMed]

86. Fang, C.; Li, H.; Li, X.; Xiao, W.; Huang, Y.; Cai, W.; Yang, Y.; Hu, J. De novo mutation of phex in a type 1 diabetes patient. J. Pediatr. Endocrinol. Metab. 2016, 29, 621-626. [CrossRef] [PubMed]

87. Tiosano, D.; Wildbaum, G.; Gepstein, V.; Verbitsky, O.; Weisman, Y.; Karin, N.; Eztioni, A. The role of vitamin $\mathrm{D}$ receptor in innate and adaptive immunity: A study in hereditary vitamin D-resistant rickets patients. J. Clin. Endocrinol. Metab. 2013, 98, 1685-1693. [CrossRef] [PubMed]

88. Ramos-Lopez, E.; Bruck, P.; Jansen, T.; Herwig, J.; Badenhoop, K. Cyp2r1 (vitamin d 25-hydroxylase) gene is associated with susceptibility to type 1 diabetes and vitamin D levels in Germans. Diabetes Metab. Res. Rev. 2007, 23, 631-636. [CrossRef] [PubMed]

89. Frederiksen, B.N.; Kroehl, M.; Fingerlin, T.E.; Wong, R.; Steck, A.K.; Rewers, M.; Norris, J.M. Association between vitamin $\mathrm{D}$ metabolism gene polymorphisms and risk of islet autoimmunity and progression to type 1 diabetes: The diabetes autoimmunity study in the young (daisy). J. Clin. Endocrinol. Metab. 2013, 98, E1845-E1851. [CrossRef] [PubMed]

90. Lopez, E.R.; Zwermann, O.; Segni, M.; Meyer, G.; Reincke, M.; Seissler, J.; Herwig, J.; Usadel, K.H.; Badenhoop, K. A promoter polymorphism of the cyp27b1 gene is associated with addison's disease, hashimoto's thyroiditis, graves' disease and type 1 diabetes mellitus in Germans. Eur. J. Endocrinol. 2004, 151, 193-197. [CrossRef] [PubMed]

91. Bailey, R.; Cooper, J.D.; Zeitels, L.; Smyth, D.J.; Yang, J.H.; Walker, N.M.; Hypponen, E.; Dunger, D.B.; Ramos-Lopez, E.; Badenhoop, K.; et al. Association of the vitamin D metabolism gene CYP27B1 with type 1 diabetes. Diabetes 2007, 56, 2616-2621. [CrossRef] [PubMed]

92. Fichna, M.; Zurawek, M.; Januszkiewicz-Lewandowska, D.; Fichna, P.; Nowak, J. Ptpn22, pdcd1 and cyp27b1 polymorphisms and susceptibility to type 1 diabetes in polish patients. Int. J. Immunogenet. 2010, 37, 367-372. [CrossRef] [PubMed]

93. Hussein, A.G.; Mohamed, R.H.; Alghobashy, A.A. Synergism of cyp2r1 and cyp27b1 polymorphisms and susceptibility to type 1 diabetes in Egyptian children. Cell. Immunol. 2012, 279, 42-45. [CrossRef] [PubMed]

94. Pani, M.A.; Donner, H.; Herwig, J.; Usadel, K.H.; Badenhoop, K. Vitamin d binding protein alleles and susceptibility for type 1 diabetes in germans. Autoimmunity 1999, 31, 67-72. [CrossRef] [PubMed]

95. Klupa, T.; Malecki, M.; Hanna, L.; Sieradzka, J.; Frey, J.; Warram, J.H.; Sieradzki, J.; Krolewski, A.S. Amino acid variants of the vitamin D-binding protein and risk of diabetes in white americans of european origin. Eur. J. Endocrinol. 1999, 141, 490-493. [CrossRef] [PubMed]

96. Ongagna, J.C.; Kaltenbacher, M.C.; Sapin, R.; Pinget, M.; Belcourt, A. The hla-dqb alleles and amino acid variants of the vitamin D-binding protein in diabetic patients in alsace. Clin. Biochem. 2001, 34, 59-63. [CrossRef]

97. Ongagna, J.C.; Pinget, M.; Belcourt, A. Vitamin d-binding protein gene polymorphism association with IA-2 autoantibodies in type 1 diabetes. Clin. Biochem. 2005, 38, 415-419. [CrossRef] [PubMed]

98. Blanton, D.; Han, Z.; Bierschenk, L.; Linga-Reddy, M.V.; Wang, H.; Clare-Salzler, M.; Haller, M.; Schatz, D.; Myhr, C.; She, J.X.; et al. Reduced serum vitamin D-binding protein levels are associated with type 1 diabetes. Diabetes 2011, 60, 2566-2570. [CrossRef] [PubMed]

99. Ramos-Lopez, E.; Lange, B.; Penna-Martinez, M.; Bruck, P.; Swiech, K.; Mauf, S.; Kahles, H.; Badenhoop, K. The role of cubilin gene polymorphisms and their influence on 25(OH)D3 and 1,25(OH)2D3 plasma levels in type 1 diabetes patients. J. Steroid Biochem. Mol. Biol. 2010, 121, 442-444. [CrossRef] [PubMed]

100. Cheng, J.B.; Levine, M.A.; Bell, N.H.; Mangelsdorf, D.J.; Russell, D.W. Genetic evidence that the human cyp2r1 enzyme is a key vitamin d 25-hydroxylase. Proc. Natl. Acad. Sci. USA 2004, 101, 7711-7715. [CrossRef] [PubMed] 
101. Thacher, T.D.; Levine, M.A. Cyp2r1 mutations causing vitamin d-deficiency rickets. J. Steroid Biochem. Mol. Biol. 2016. [CrossRef] [PubMed]

102. Cheng, J.B.; Motola, D.L.; Mangelsdorf, D.J.; Russell, D.W. De-orphanization of cytochrome p450 2r1: A microsomal vitamin d 25-hydroxilase. J. Biol. Chem. 2003, 278, 38084-38093. [CrossRef] [PubMed]

103. Miller, W.L. Genetic disorders of vitamin d biosynthesis and degradation. J. Steroid Biochem. Mol. Biol. 2017, 165, 101-108. [CrossRef] [PubMed]

104. Yu, O.B.; Arnold, L.A. Calcitroic acid-A review. ACS Chem. Biol. 2016, 11, 2665-2672. [CrossRef] [PubMed]

105. Schlingmann, K.P.; Kaufmann, M.; Weber, S.; Irwin, A.; Goos, C.; John, U.; Misselwitz, J.; Klaus, G.; Kuwertz-Broking, E.; Fehrenbach, H.; et al. Mutations in cyp24a1 and idiopathic infantile hypercalcemia. N. Engl. J. Med. 2011, 365, 410-421. [CrossRef] [PubMed]

106. Chun, R.F.; Lauridsen, A.L.; Suon, L.; Zella, L.A.; Pike, J.W.; Modlin, R.L.; Martineau, A.R.; Wilkinson, R.J.; Adams, J.; Hewison, M. Vitamin D-binding protein directs monocyte responses to 25-hydroxy- and 1,25-dihydroxy vitamin D. J. Clin. Endocrinol. Metab. 2010, 95, 3368-3376. [CrossRef] [PubMed]

107. Onengut-Gumuscu, S.; Chen, W.M.; Burren, O.; Cooper, N.J.; Quinlan, A.R.; Mychaleckyj, J.C.; Farber, E.; Bonnie, J.K.; Szpak, M.; Schofield, E.; et al. Fine mapping of type 1 diabetes susceptibility loci and evidence for colocalization of causal variants with lymphoid gene enhancers. Nat. Genet. 2015, 47, 381-386. [CrossRef] [PubMed]

108. Singh, P.K.; van den Berg, P.R.; Long, M.D.; Vreugdenhil, A.; Grieshober, L.; Ochs-Balcom, H.M.; Wang, J.; Delcambre, S.; Heikkinen, S.; Carlberg, C.; et al. Integration of VDR genome wide binding and gwas genetic variation data reveals co-occurrence of VDR and NF-kappab binding that is linked to immune phenotypes. BMC Genom. 2017, 18, 132. [CrossRef] [PubMed]

109. Ramagopalan, S.V.; Heger, A.; Berlanga, A.J.; Maugeri, N.J.; Lincoln, M.R.; Burrell, A.; Handunnetthi, L.; Handel, A.E.; Disanto, G.; Orton, S.M.; et al. A chip-seq defined genome-wide map of vitamin D receptor binding: Associations with disease and evolution. Genome Res. 2010, 20, 1352-1360. [CrossRef] [PubMed]

110. Eerligh, P.; Koeleman, B.P.; Dudbridge, F.; Jan Bruining, G.; Roep, B.O.; Giphart, M.J. Functional genetic polymorphisms in cytokines and metabolic genes as additional genetic markers for susceptibility to develop type 1 diabetes. Genes Immun. 2004, 5, 36-40. [CrossRef] [PubMed]

111. Holick, M.F. Vitamin D: A D-lightful solution for health. J. Investig. Med. 2011, 59, 872-880. [CrossRef] [PubMed]

112. Muscogiuri, G.; Mitri, J.; Mathieu, C.; Badenhoop, K.; Tamer, G.; Orio, F.; Mezza, T.; Vieth, R.; Colao, A.; Pittas, A. Mechanisms in endocrinology: Vitamin D as a potential contributor in endocrine health and disease. Eur. J. Endocrinol. 2014, 171, R101-R110. [CrossRef] [PubMed]

113. Anonymous. Vitamin D supplement in early childhood and risk for type I (insulin-dependent) diabetes mellitus. The eurodiab substudy 2 study group. Diabetologia 1999, 42, 51-54.

114. Hypponen, E.; Laara, E.; Reunanen, A.; Jarvelin, M.R.; Virtanen, S.M. Intake of vitamin D and risk of type 1 diabetes: A birth-cohort study. Lancet 2001, 358, 1500-1503. [CrossRef]

115. Bogdanou, D.; Penna-Martinez, M.; Filmann, N.; Chung, T.L.; Moran-Auth, Y.; Wehrle, J.; Cappel, C.; Huenecke, S.; Herrmann, E.; Koehl, U.; et al. T-lymphocyte and glycemic status after vitamin D treatment in type 1 diabetes: A randomized controlled trial with sequential crossover. Diabetes Metab. Res. Rev. 2017, 33, e2865. [CrossRef] [PubMed]

116. Moran-Auth, Y.; Penna-Martinez, M.; Badenhoop, K. Vdr foki polymorphism is associated with a reduced t-helper cell population under vitamin D stimulation in type 1 diabetes patients. J. Steroid Biochem. Mol. Biol. 2015, 148, 184-186. [CrossRef] [PubMed]

117. Mauf, S.; Penna-Martinez, M.; Jentzsch, T.; Ackermann, H.; Henrich, D.; Radeke, H.H.; Bruck, P.; Badenhoop, K.; Ramos-Lopez, E. Immunomodulatory effects of 25-hydroxyvitamin $\mathrm{D}_{3}$ on monocytic cell differentiation and influence of vitamin $\mathrm{D}_{3}$ polymorphisms in type 1 diabetes. J. Steroid Biochem. Mol. Biol. 2015, 147, 17-23. [CrossRef] [PubMed]

(c) 2017 by the authors. Licensee MDPI, Basel, Switzerland. This article is an open access article distributed under the terms and conditions of the Creative Commons Attribution (CC BY) license (http:/ / creativecommons.org/licenses/by/4.0/). 